\title{
Studies on the isopropylbenzene 2,3-dioxygenase and the 3-isopropylcatechol 2,3-dioxygenase genes encoded by the linear plasmid of Rhodococcus erythropolis BD2
}

\author{
Maria Kesseler, ${ }^{1}$ Eric R. Dabbs, ${ }^{2}$ Beate Averhoff' ${ }^{1}$ and Gerhard Gottschalk ${ }^{1}$
}

1 Institut für Mikrobiologie der Georg-AugustUniversităt, Grisebachstraße 8, D-37077 Gottingen, Germany

2 University of the Witwatersrand, Johannesburg, South Africa
Author for correspondence: Beate Averhoff. Tel: +49551 394041. Fax: +49551393793. e-mail: BAVERHO@gwdg.de

The enzymes responsible for the degradation of isopropylbenzene (IPB) and cooxidation of trichloroethene (TCE) by Rhodococcus erythropolis BD2 are encoded by the linear plasmid pBD2. Fragments containing IPB catabolic genes were cloned from PBD2 and the nucleotide sequence was determined. By means of database searches and expression of the cloned genes in recombinant strains, we identified five clustered genes, ipbA1A2A3A4C, which encode the three components of the IPB 2,3-dioxygenase system, reductase ${ }_{\mathrm{IPB}}$ (ipbA4), ferredoxin ${ }_{1 \mathrm{~PB}}(\mathrm{ipbA3})$ and the two subunits of the terminal dioxygenase (ipbA1A2), as well as the 3-isopropylcatechol (IPC) 2,3dioxygenase (ipbC). The protein sequences deduced from the ipbA1A2A3A4C gene cluster exhibited significant homology with the corresponding proteins of analogous degradative pathways in Gram-negative and Gram-positive bacteria, but the gene order differed from most of them. IPB 2,3-dioxygenase and 3-IPC 2,3-dioxygenase could both be expressed in Escherichia coli, but the IPB 2,3-dioxygenase activities were too low to be detected by polarographic and TCE degradative means. However, inhibitor studies with the $R$. erythropolis BD2 wild-type are in accordance with the involvement of the IPB 2,3-dioxygenase in TCE oxidation.

Keywords: Rbodococcus erythropolis, isopropylbenzene 2,3-dioxygenase, 3-isopropylcatechol 2,3-dioxygenase, trichloroethene co-oxidation

\section{INTRODUCTION}

Multicomponent oxygenases often play a dual crucial role in the bacterial degradation of aromatic and chlorinated aliphatic compounds (Ensley, 1991). They catalyse the oxygenation of their inducer substrates and in addition oxidize chloroalkenes such as trichloroethene (TCE), a toxic groundwater contaminant with suspected carcinogenic activity which is widely distributed throughout the world (Miller \& Guengerich, 1983). Since the first documentation by Nelson et al. (1986) of a pure culture capable of metabolizing TCE under aerobic conditions, a number of TCE-degrading micro-organisms have been

Abbreviations: IPB, isopropylbenzene; IPC, isopropylcatechol; Plac, lactose operon promoter; Ptac, hybrid promoter of the lactose and the tryptophan operon; TCE, trichloroethene.

The GenBank accession number for the sequences reported in this paper is U24277. isolated (Ensley, 1991). Most investigations on TCE degradation have addressed Gram-negative bacteria and revealed that TCE is only biodegradable through cometabolic transformation processes mediated by oxygenases which exhibit broad substrate specificities, such as monooxygenases acting on methane (Oldenhuis et al., 1989), propane (Wackett $e t$ al., 1989), isoprene (Evers $e t$ al., 1990), ammonia (Arciero et al., 1989), toluene (Whited \& Gibson, 1991) or phenol (Folsom et al., 1990). By analogy with metabolism of chlorinated alkenes by mammalian cytochrome P-450 monooxygenase, bacterial oxygenases might also activate TCE and release intermediate reaction products, such as TCE epoxide and chloral, which produce cytotoxic effects. So far, only one dioxygenase of a Gram-negative micro-organism, the toluene dioxygenase of $P$ seudomonas putida $\mathrm{F} 1$, is known to oxidize TCE (Nelson et al., 1988; Wackett \& Householder, 1989). Two representatives of Gram-positive genera, isoprene-oxidizer Rbodococcus erythropolis strain JE77 and the propane-utilizer Mycobacterium vaccae, have 
been reported to co-oxidize TCE (Wackett et al., 1989; Evers et al., 1990).

Recently, we described R. erythropolis strain BD2, which is able to grow with isopropylbenzene (IPB) and to cooxidize TCE (Dabrock et al., 1992). This observation suggested that an inducible enzyme of the IPB degradative pathway is involved in TCE degradation. R. erytbropolis $\mathrm{BD} 2$ transforms IPB by oxidation of the aromatic ring to give 3-isopropylcatechol (IPC), which subsequently undergoes a meta-cleavage reaction leading to the formation of 2-hydroxy-6-oxo-7-methylocta-2,4-dienoate. Interestingly, all three characteristics, the IPB-oxidizing activity, the meta-cleavage activity and the degradation of TCE, are encoded by a linear plasmid, named pBD2 (a $208 \mathrm{~kb}$ linear DNA plasmid recently detected in $R$. erythropolis strain BD2; Dabrock et al., 1994).

To analyse the molecular and biochemical basis of IPB oxidation and TCE co-oxidation, the genes encoding the IPB 2,3-dioxygenase (ipb $A 1 A 2 A 3 A 4)$ and the 3-IPC 2,3dioxygenase $(i p b C)$ of $\mathrm{BD} 2$ have been cloned and sequenced. Comparisons of the deduced amino acid sequences were made with those encoded by analogous genes of other catabolic pathways. They revealed differences in arrangement but a high degree of homology, so that a common origin of these pathways is indicated.

\section{METHODS}

Bacterial strains, growth conditions and plasmids. Rhodococcus erythropolis strain $\mathrm{BD} 2$, which was recently isolated in our laboratory, was grown in M3 minimal salt medium with IPB as carbon and energy source as described previously (Dabrock et al., 1994). R. erytbropolis strain SQ1 (Quan \& Dabbs, 1993) was grown on Luria-Bertani (LB) medium (Miller, 1972) at $30^{\circ} \mathrm{C}$ as were the Eschericbia coli strains MM294 (Bachmann, 1987),

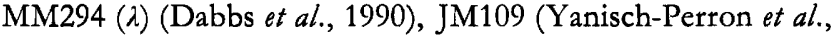
1985) and XL1-Blue (Bullock et al., 1987). E. coli strains carrying recombinant plasmids derived from pBluescript II KS/SK (+ / - ) (Stratagene), pKK223-3 (Pharmacia Biosystems) or pDA71 (E. R. Dabbs) were selected on LB agar containing ampicillin $\left(100 \mu \mathrm{g} \mathrm{ml}^{-1}\right)$. The plasmids used in this study are listed in Table 1.

DNA manipulations and transformation of rhodococci. Standard recombinant DNA techniques were performed according to Sambrook et al. (1989). The R. erytbropolis BD2 linear plasmid was isolated as described previously (Dabrock et al., 1994). For transformation of $R$. erytbropolis SQ1, $100 \mathrm{ml}$ cultures were grown on LB medium containing $1.8 \%(\mathrm{w} / \mathrm{v})$ sucrose, $1.5 \%(\mathrm{w} / \mathrm{v})$ glycine and $0.01 \%$ isonicotinic acid hydrazide to an $\mathrm{OD}_{600}$ of $3 \cdot 0$, harvested, washed twice with ice-cold, sterile distilled water and resuspended in $1 \mathrm{ml} 30 \%$ (w/v) PEG to reach an $\mathrm{OD}_{600}$ of 300 . Aliquots of $100 \mu \mathrm{l}$ were stored at $-70^{\circ} \mathrm{C}$. For transformation, Rhodococcus cells were thawed on ice, mixed with $\leqslant 1 \mu \mathrm{g}$ DNA, transferred into a chilled electroporation cuvette $(0.2 \mathrm{~cm} ;$ Bio-Rad) and incubated on ice for $10 \mathrm{~min}$. Electroporation was performed at $2.5 \mathrm{kV}, 25 \mu \mathrm{F}$ and $400 \Omega$, yielding time constants of about $6.8 \mathrm{~ms}$ (Gene pulser; Bio-Rad). LB medium (1 $\mathrm{ml}$ ) was added and cells were spread on LB agar. After $6 \mathrm{~h}, 250 \mu \mathrm{l}$ of a chloramphenicol stock solution was added underneath the agar $\left(40 \mu \mathrm{g} \mathrm{ml}^{-1}\right.$ final concentration) to select for transformants carrying pDA71 or derivatives.

Screening for IPB- and IPC-transforming activities. To screen for IPB-2,3-dioxygenase-catalysed indole oxidation, R. erytbropolis SQ1 transformants were grown on LB medium containing chloramphenicol $\left(40 \mu \mathrm{g} \mathrm{ml}^{-1}\right)$ and indole $(1 \mathrm{mM})$. IPB was

Table 1. Plasmids used in this work

\begin{tabular}{|c|c|c|}
\hline Plasmid & Relevant characteristics & Source/reference \\
\hline pBluescript II KS/SK $(+/-)$ & Cloning vectors, $A p^{r}$ & Stratagene \\
\hline pKK223-3 & Expression vector, $\mathrm{Ap}^{\mathrm{r}}$, Ptac & Pharmacia Biosystems \\
\hline pDA71 & E. coli-Rhodococcus shuttle vector, $\mathrm{Ap}^{\mathrm{r}} \mathrm{Cm}^{\mathrm{r}}$ & E. R. Dabbs \\
\hline pBD2 & Linear megaplasmid of IPB degrader R. erythropolis BD2 & Dabrock et al. (1994) \\
\hline pDTG601 & $\begin{array}{l}\text { pKK223-3 recombinant plasmid encoding todC1C2B } A \\
\text { from } P . \text { putida } \mathrm{F} 1\end{array}$ & Zylstra \& Gibson (1989) \\
\hline pMKD107 & $\mathrm{pDA} 71$ with $6.4 \mathrm{~kb} B c l \mathrm{I}$ fragment of $\mathrm{pBD} 2$ carrying $i p b A C$ & \\
\hline pMKD119 & pDA71 with $7.5 \mathrm{~kb} B c l$ fragment of $\mathrm{pBD} 2$ carrying $i p b C B$ & \\
\hline pMKD205 & pDA71 with $4.2 \mathrm{~kb} B s t \mathrm{YI}$ fragment of $\mathrm{pBD} 2$ carrying $i p b C$ & \\
\hline $\operatorname{pMK1}(+/-)$ & $\begin{array}{l}\text { pBluescript II KS with } 3.5 \mathrm{~kb} \text { EcoRI-NotI fragment of } \\
\text { pMKD107 }\end{array}$ & \\
\hline $\mathrm{pMK} 2(+/-)$ & $\begin{array}{l}\text { pBluescript II KS with } 2.6 \mathrm{~kb} \text { NotI-EcoRV fragment of } \\
\text { pMKD107 carrying } i \not p b C\end{array}$ & \\
\hline $\mathrm{pMK} 3(+/-)$ & $\begin{array}{l}\text { pBluescript II SK with } 4 \cdot 2 \mathrm{~kb} B g I \mathrm{II}-E c o \mathrm{RI} \text { fragment of } \\
\text { pMKD107 carrying ipb } A \text { under control of Plac }\end{array}$ & This work \\
\hline $\operatorname{pMK} 4(+/-)$ & 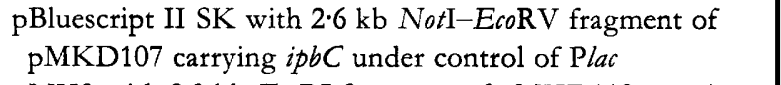 & \\
\hline pMK34 (+/-) & $\begin{array}{l}\text { pMK3 with } 2 \cdot 0 \mathrm{~kb} E c o \mathrm{RI} \text { fragment of } \mathrm{pMKD} 119 \text { carrying } \\
i p b A C B \text { under control of Plac }\end{array}$ & \\
\hline pKKM2 & $\begin{array}{l}\text { pKK223-3 with } 2.6 \mathrm{~kb} \text { PstI-HindIII fragment of } \\
\text { pMKD107 carrying ipbC under control of Ptac }\end{array}$ & \\
\hline pKKID5 & $\begin{array}{l}\text { pKK223-3 with } 4.9 \mathrm{~kb} E c o \mathrm{RI} \text { fragment of pMKD107 } \\
\text { carrying ipb } A \text { under control of Ptac }\end{array}$ & \\
\hline
\end{tabular}


supplied via the gas phase to guarantee induction of the $i p b$ genes. In the presence of indole, colonies with IPB 2,3dioxygenase (IpbA) activity turn blue due to the formation of indigo from indole. Transformants carrying DNA fragments encoding 3-IPC 2,3-dioxygenase (IpbC) activity were detected by a catechol or 3-IPC spray assay (Furukawa \& Miyazaki, 1986) for the production of the yellow-coloured meta-cleavage products, such as 2-hydroxymuconic semialdehyde or 2-hydroxy-6oxo-7-methylocta-2,4-dienoate. For activity staining of $E$. coli transformants, IPTG was added to a final concentration of $0.1 \mathrm{mM}$ to solid LB media and $0.5 \mathrm{mM}$ to liquid LB media. Indole, the substrate for indigo production, could be omitted from media for growth of $E$. coli recombinant strains because it was provided by the $E$. coli tryptophanase.

Southern hybridization. Southern blots of the cloned pBD2 fragments were performed with nylon membranes (GeneScreen Plus; DuPont, NEN Research products). Hybridizations with ${ }^{32}$ P-labelled DNA were carried out according to Anderson \& Young (1985). Experiments were done under low-stringency conditions as described previously by Dabrock et al. (1994). The heterologous toluene dioxygenase genes from $P$. putida F1 (todC1C2B $A$ ) carried on plasmid pDTG601 (Zylstra \& Gibson, 1989) were kindly provided by D. T. Gibson, University of Iowa, USA.

Subcloning and nucleotide sequencing. DNA fragments carrying ipb genes were subcloned into pBluescript II $\mathrm{KS} / \mathrm{SK}(+/-)$ or pKK223-3 by making use of the corresponding restriction maps and an Erase-a-base kit (Promega) to obtain a series of deletion derivatives. Single-stranded DNA of these clones was isolated (Vieira \& Messing, 1987) and nucleotide sequences were determined by the dideoxy termination method (Sanger et al., 1977) with an automated sequencing kit (Pharmacia) and analysed with the GCG package referring to SWISS-PROT and EMBL data.

Identification of gene products. Expression of the cloned $i p b$ genes was performed in vitro with the corresponding pKK2233 derivatives using an $E$. coli $\mathrm{S} 30$ extract system (Promega) and L- $\left[{ }^{35}\right.$ S $]$ methionine (Hartmann). After SDS-PAGE analysis according to the method of Schägger \& von Jagow (1987), the gel was stained with Coomassie Brillant Blue (Serva), dried for $40 \mathrm{~min}$ at $60^{\circ} \mathrm{C}$ in a vacuum gel dryer (Bio-Rad) and exposed to $\mathrm{X}$-ray film.

Enzyme assays and analysis of substrate specificity. For IPB 2,3-dioxygenase and 3-IPC 2,3-dioxygenase activity assays, $R$. erythropolis BD2 cells were grown in $60 \mathrm{ml} \mathrm{M} 3$ minimal medium with a supply of IPB in the vapour phase as described previously by Dabrock et al. (1994), harvested at an $\mathrm{OD}_{600}$ of $1 \cdot 0$, washed twice and resuspended in $300 \mu 150 \mathrm{mM}$ phosphate buffer $(\mathrm{pH}$ 7.0). The 3-IPC 2,3-dioxygenase activity in E. coli recombinant cells carrying pBluescript II KS (negative control), pMK2, pMK4, pMK34 or pKKM2 was induced with IPTG $(0.5 \mathrm{mM})$ in the early-exponential phase during growth $\left(\mathrm{OD}_{600} 0 \cdot 15-0 \cdot 2\right)$ in $30 \mathrm{ml} \mathrm{LB}$ medium containing ampicillin $\left(50 \mu \mathrm{g} \mathrm{ml}^{-1}\right)$. At an $\mathrm{OD}_{600}$ of $0 \cdot 6$, cells were harvested, washed and resuspended in $100 \mu \mathrm{l} 50 \mathrm{mM}$ phosphate buffer ( $\mathrm{pH} \mathrm{7 \cdot 0}$ ). Recombinant $\mathrm{R}$. erytbropolis SQ1 cells carrying PMKD107 were similarly treated but grown in the presence of chloramphenicol $\left(40 \mu \mathrm{g} \mathrm{ml}^{-1}\right)$ instead of ampicillin, induced by IPB via the vapour phase and harvested at varying $\mathrm{OD}_{600}$ values of $0.5-1.9$ with an optimal activity at the early-exponential phase $\left(\mathrm{OD}_{600} 0 \cdot 5-1 \cdot 0\right)$.

Substrate-dependent oxygen-uptake rates of the cells were followed by a Clark oxygen electrode (Rank Brothers) at $30^{\circ} \mathrm{C}$ in $2 \mathrm{ml} 50 \mathrm{mM}$ phosphate buffer ( $\mathrm{pH} 7 \cdot 0$ ). Substrate-independent oxygen consumption was measured for $3 \mathrm{~min}$ before IPB or meta-cleavage substrates like 3-IPC, catechol or 3-methylcatechol were added to a final concentration of $200 \mu \mathrm{M}$ and the total oxygen uptake was followed for $6 \mathrm{~min}$. The difference in the substrate-dependent oxygen-uptake rate and substrateindependent oxygen-uptake rate was defined as the IPB or 3-IPC 2,3-dioxygenase activity, respectively $\left(1 \mathrm{nmol} \mathrm{min} \mathrm{mg}^{-1} \mathrm{mg}^{-1}=\right.$ $1 \mathrm{mU})$. Protein content was measured by the method of Schmidt et al. (1963).

Inhibitor studies. Cultures $(100 \mathrm{ml})$ of $\mathrm{R}$. erytbropolis $\mathrm{BD} 2$ were grown for $24 \mathrm{~h}$ in minimal medium in the presence of IPB as sole carbon source and re-fed as described previously by Dabrock et al. (1992). Cells were harvested by centrifugation, washed once and resuspended in $1.5 \mathrm{ml}$ sodium/potassium phosphate buffer supplemented with $5 \mathrm{mM} \mathrm{MgSO}_{4}$. Cell suspensions were incubated for $5 \mathrm{~min}$ in the presence of $0-0.66 \mu \mathrm{mol} 3$-chlorocatechol ( $\mathrm{mg}$ protein $)^{-1}$ before substratedependent oxygen uptake was measured with IPB and 3-IPC, respectively. The degradation of TCE by IPB-induced $\mathrm{BD} 2$ cells in the presence of the meta-cleavage inhibitor 3-chlorocatechol $\left.[0.33 \mu \mathrm{mol} \text { ( } \mathrm{mg} \text { protein })^{-1}\right]$ was quantified by headspace gas chromatography as described previously by Dabrock $e t$ al. (1992).

\section{RESULTS}

\section{Cloning and mapping of the ipb genes}

Two libraries of the R. erytbropolis $\mathrm{BD} 2$ linear plasmid pBD2 $(208 \mathrm{~kb})$ were constructed by ligation of pBD2 DNA partially digested with $B c l \mathrm{I}$ or $B s t \mathrm{YI}$ into the $B g l \mathrm{II}-$ linearized E. coli-Rhodococcus shuttle vector pDA71. After transformation of E. coli MM294, plasmid DNA of pooled colonies was isolated and transformed into R. erytbropolis SQ1 as described in Methods. When approximately $2 \times 10^{4}$ colonies were screened for meta-cleavage activity by spraying with both 3-IPC and catechol, 50 colonies turned yellow, indicating meta-cleavage activity of the 3IPC 2,3-dioxygenase (IpbC). Recombinant plasmids from 30 colonies were isolated and found to carry a $4.2 \mathrm{~kb}$ $B s t \mathrm{YI}$ (pMKD205), a $6.4 \mathrm{~kb} \mathrm{Bc/I}$ (pMKD107) or a $7.5 \mathrm{~kb}$ $B c l$ (pMKD119) insert in pDA71 (Fig. 1). Expression of $i p b C$ in SQ1 carrying pMK205, pMK107 or pMKD119 was not stimulated by potential inducer substrates such as IPB or 3-IPC. Subcloning experiments proved that the $B c l$ I-HindIII fragment within the $1.6 \mathrm{~kb}$ overlapping region of the different clones was responsible for metacleavage activity. Retransfer of the recombinant plasmids into $E$. coli MM294 and restriction analysis revealed that the two $B c l$ fragments were overlapping within a $1.6 \mathrm{~kb}$ DNA region, while the $B s t$ YI fragment was completely within the $6.4 \mathrm{~kb} B c / \mathrm{I}$ fragment (Fig. 1). Examination of the recombinant $E$. coli clones for 3-IPC 2,3-dioxygenase activities by using the 3-IPC and catechol spray assay revealed no 3-IPC 2,3-dioxygenase activities, indicating that the R. erytbropolis BD2 $i p b C$ gene is not expressed in E. coli in pDA71.

Southern hybridization experiments performed with linear $\mathrm{pBD} 2 \mathrm{DNA}$ and heterologous DNA probes of the toluene dioxygenase genes $(\operatorname{tod} C 1 C 2 B A)$ from $P$. putida F1, which we have published recently (Dabrock et al., 1994), already indicated a significant homology between the toluene dioxygenase genes and the presumed IPB 2,3- 


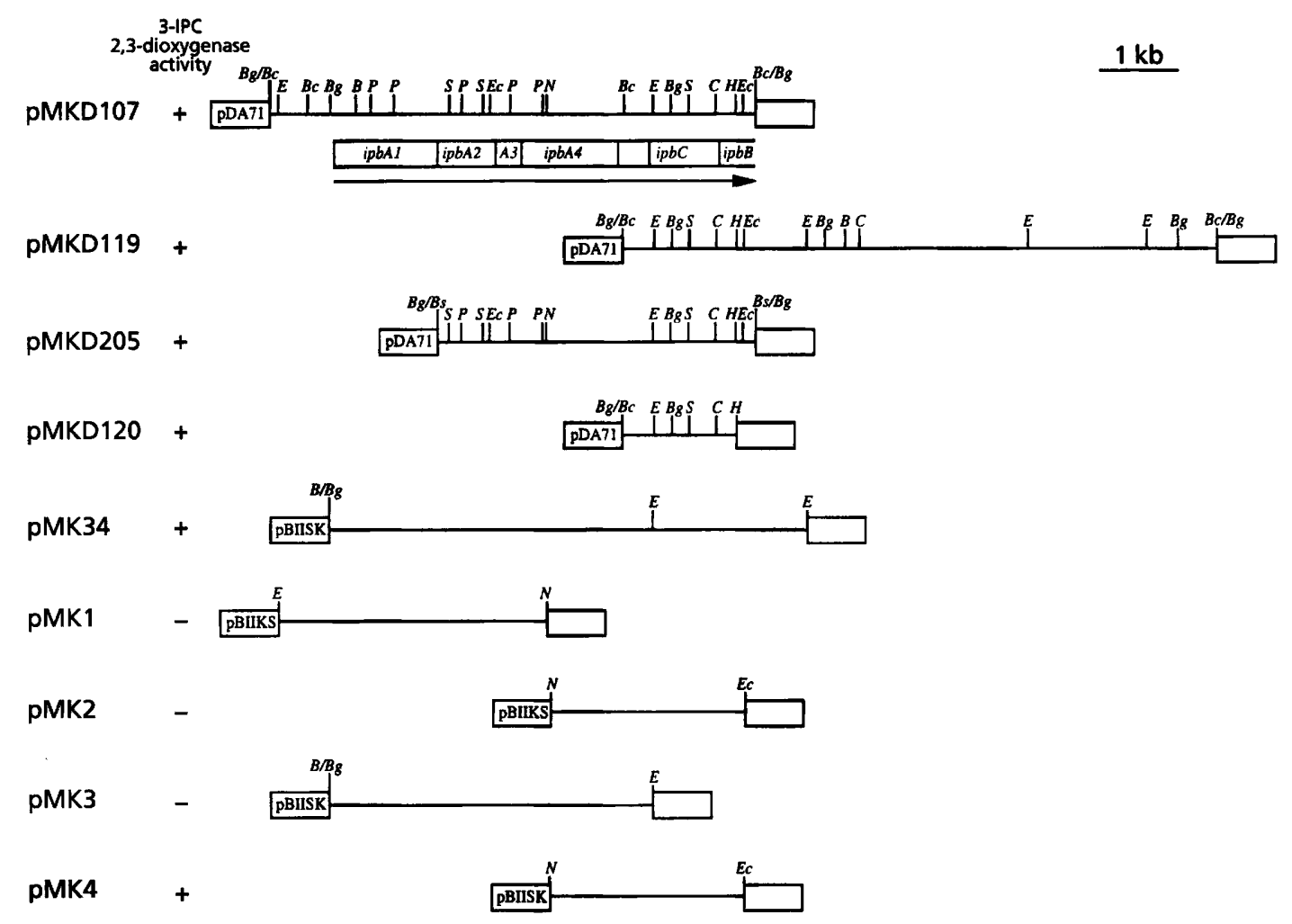

Fig. 1. Cloning and subcloning of the ipb genes. pBD2 fragments from $B c / l$ and $B s t Y 1$ partial digests were ligated into the suicide shuttle vector pDA71, generating PMKD107, pMKD119 and pMKD205. Corresponding recombinant $R$. erythropolis SQ1 colonies and $E$. coli XL1-Blue carrying derived recombinant pBluescript II plasmids were sprayed with catechol $(100 \mathrm{mM})$ to detect meta-cleavage activity (yellow colour; + ). The arrow indicates the direction of transcription deduced from nucleotide sequence analysis and expression of the extradiol dioxygenase IpbC. pBIISK, pBluescript II SK; pBIIKS, pBluescript II KS; B, BamHI; BC, Bcll; Bg, Bg/ll; Bs, BstYI; C, Clal; E, EcoRI; EC, EcoRV; H, HindlII; N, Notl; P, Pstl; S, Sall.

dioxygenase genes of $\mathrm{R}$. erytbropolis $\mathrm{BD} 2$. In order to identify IPB 2,3-dioxygenase genes, insert DNA of pMKD107, pMKD119 and pMKD205 was hybridized with the ${ }^{32} \mathrm{P}$-labelled toluene dioxygenase gene probe. Clear hybridization signals were observed with pMKD107 and pMKD205, but not with pMKD119. These results provided strong evidence for the localization of the IPB 2,3-dioxygenase genes on pMKD107 and $\mathrm{pMKD} 205$.

\section{Sequence analysis}

The $3.5 \mathrm{~kb}$ EcoRI-NotI and the $2.6 \mathrm{~kb}$ NotI-EcoRV fragments of pMKD107 were cloned into pBluescript II $\mathrm{KS}$, yielding pMK1 and pMK2, respectively (Fig. 1). pMK1 and pMK2 were then subjected to partial digestion with exonuclease III to construct overlapping deletion series for sequence analysis of one strand. Making use of the predicted restriction sites, deletion plasmids for sequence analysis of the other strand were constructed. Complete sequence data of the $5.7 \mathrm{~kb}$ EcoRI-ClaI DNA region are presented in Fig. 2. Five ORFs were found with significant homology to genes encoding aromaticring-activating multicomponent dioxygenases and extradiol dioxygenases of aromatic hydrocarbon degraders. Based on the homology and the hybridization data as well as on the meta-cleavage activity, ORFs $1-4$ were identified as the cistrons for the $\alpha$-and $\beta$-subunit of the iron-sulfur protein, the ferredoxin, and the ferredoxin reductase components of a multicomponent IPB 2,3-dioxygenase (IpbA1A2A3A4), while ORF5 was found to encode the 3IPC 2,3-dioxygenase (IpbC). The potential Shine-Dalgarno sequences preceding the $i p b$ genes are underlined in Fig. 2. Further sequence analysis of the DNA downstream of $i p b C$ (ClaI-BclI fragment) strongly suggested the presence of $i p b B$ encoding the IPB 2,3-dihydrodiol dehydrogenase (data not shown).

\section{Sequence comparisons and organization of the ipb genes}

IpbAC of R. erytbropolis BD2 showed high homologies (54-78\% amino acid identity) with other ring-hydroxylating and meta-cleaving dioxygenases of toluene, benzene and biphenyl degradative pathways in Pseudomonas strains (Table 2), such as $P$. putida F1 (Zylstra \& Gibson, 1989), Pseudomonas sp. P51 (Van der Meer et al., 1991), P. putida ML2 (Tan et al., 1993) and Pseudomonas pseudoalcaligenes KF707 (Taira et al., 1992). Amino acid identities with BphAC1 from R. globerulus P6 (Asturias et al., 1994, 1995) are $59 \cdot 4-79 \cdot 5 \%$ and with the biphenyl dioxygenase and the 2,3-dihydroxybiphenyl dioxygenase from Rhodococcus 

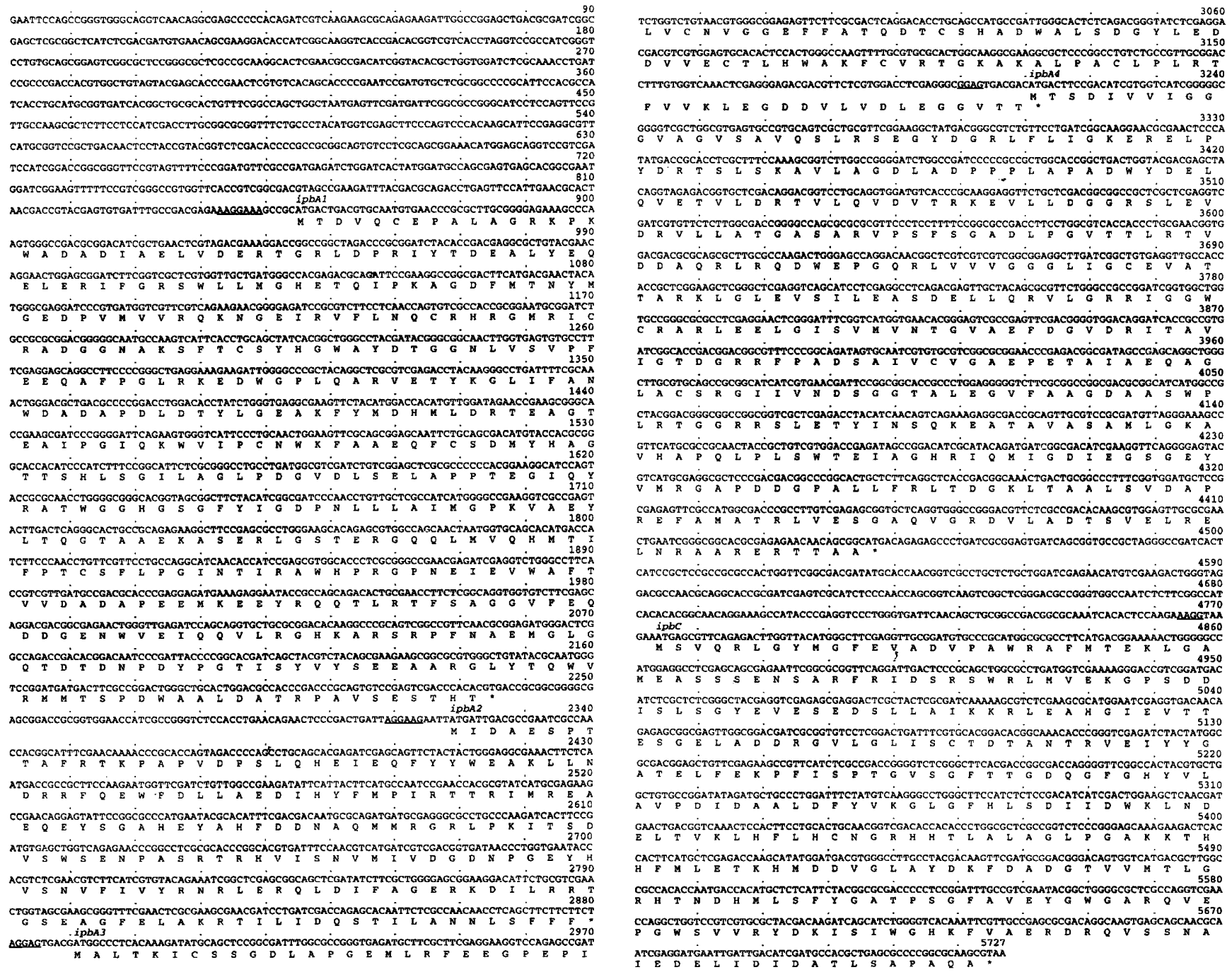

Fig. 2. Nucleotide sequence of the $R$. erythropolis BD2 ipbA1A2A3A4C genes and the corresponding amino acid sequences. Putative ribosome-binding sites are underlined.

Table 2. Comparison of the deduced amino acid sequences of the individual components of IPB dioxygenase and 3-IPC 2,3-dioxygenase from $R$. erythropolis BD2 encoded by the ipbA1A2A3A4 and ipbC genes with the corresponding dioxygenases of analogous pathways in Rhodococcus and Pseudomonas species, respectively

Values give percentages of identical amino acids. Dioxygenases: biphenyl dioxygenase (BphA1A2A3A4) and 2,3-dihydroxybiphenyl dioxygenase (BphC) from Rbodococcus sp. RHA1 (Masai et al., 1995); biphenyl dioxygenase (BphA1A2A3A4) and 2,3-dihydroxybiphenyl 1,2-dioxygenase (BphC1) from R. globerulus P6 (Asturias et al., 1994, 1995); toluene dioxygenase (TodC1C2BA) and 3-methylcatechol 2,3dioxygenase (TodE) from $P$. putida F1 (Zylstra \& Gibson, 1989); 1,2,4-trichlorobenzene 5,6-dioxygenase (TcbAaAbAcAd) from Pseudomonas sp. P51 (Van der Meer et al., 1991); benzene dioxygenase (BedC1C2BA) from P. putida ML2 (Tan et al., 1993); and biphenyl dioxygenase (BphA1A2A3A4) and 2,3-dihydroxybiphenyl 1,2-dioxygenase (BphC) from P. pseudoalcaligenes KF707 (Taira et al., 1992 ).

\begin{tabular}{|lcccccc|}
\hline $\begin{array}{l}\text { R. erythropolis } \\
\text { BD2 }\end{array}$ & $\begin{array}{c}\text { Rhodococcus } \\
\text { sp. RHA1 }\end{array}$ & $\begin{array}{c}\text { R. globerulus } \\
\text { P6 }\end{array}$ & $\begin{array}{c}\text { P. putida } \\
\text { F1 }\end{array}$ & $\begin{array}{c}\text { Pseudomonas } \\
\text { sp. P51 }\end{array}$ & $\begin{array}{c}\text { P. putida } \\
\text { ML2 }\end{array}$ & $\begin{array}{c}\text { P. pseudoalcaligenes } \\
\text { KF707 }\end{array}$ \\
\hline IpbA1 & $98 \cdot 9$ & $79 \cdot 5$ & $77 \cdot 7$ & $78 \cdot 4$ & $76 \cdot 3$ & $67 \cdot 6$ \\
IpbA2 & $95 \cdot 7$ & $69 \cdot 0$ & $77 \cdot 5$ & $76 \cdot 5$ & $74 \cdot 9$ & $56 \cdot 7$ \\
IpbA3 & $98 \cdot 1$ & $59 \cdot 2$ & $68 \cdot 3$ & $68 \cdot 3$ & $65 \cdot 4$ & $54 \cdot 3$ \\
IpbA4 & $87 \cdot 4$ & $59 \cdot 4$ & $56 \cdot 9$ & $57 \cdot 6$ & $55 \cdot 7$ & $54 \cdot 4$ \\
IpbC & $98 \cdot 4$ & $70 \cdot 1$ & $70 \cdot 0$ & & & $56 \cdot 0$ \\
\hline
\end{tabular}




\begin{tabular}{|c|c|c|c|c|c|c|}
\hline \multirow[t]{2}{*}{ BD2 } & $i p b A I$ & $i p b A 2$ & $A 3$ & ipbA4 & $i p b c$ & $i p b B$ \\
\hline & 460 aa & $187 \mathrm{aa}$ & 107 aа & $412 \mathrm{aa}$ & \multicolumn{2}{|c|}{317 aа } \\
\hline \multirow[t]{2}{*}{ P6 } & bphAl & $b b p h A 2$ & $A 3$ & bphA4 & $b p h B$ & bphCl \\
\hline & 461 aa & 186aa & 108 aa & $412 \mathrm{aa}$ & $280 \mathrm{aa}$ & $291 \mathrm{aa}$ \\
\hline \multirow[t]{2}{*}{ RHAl } & bphAl & bphA2 & $A 3$ & bphA4 & $b p h C$ & bphB \\
\hline & 460 aa & 187 aa & $107 a$ & $413 \mathrm{aa}$ & 317 aа & 263 аa \\
\hline \multirow[t]{2}{*}{ F1 } & todCl & $\operatorname{tod} C 2$ & $B$ & todA & $\operatorname{tod} D$ & \multirow{2}{*}{ todE } \\
\hline & $450 \mathrm{aa}$ & $187 \mathrm{aa}$ & $107 \mathrm{aa}$ & 410 aa & aa & \\
\hline
\end{tabular}

Fig. 3. Organization of the ipb genes in R. erythropolis BD2 and comparison with the operon structures of analogous biphenyl degradative pathways in $R$. globerulus P6 (Asturias et al., 1994, 1995) and Rhodococcus sp. RHA1 (Masai et al., 1995) and the toluene degradative pathway in P. putida F1 (Zylstra \& Gibson, 1989). The arrow indicates the direction of transcription. ND, Not determined.

sp. RHA1 even $87 \cdot 4-98 \cdot 9 \%$ (Masai et al., 1995). The latter scores are surprisingly high and, therefore, growth of $R$. erythropolis BD2 with biphenyl in liquid culture was tested. No increase of the optical density was observed. BD2 cells grown on IPB and spread on plates with a supply of biphenyl in the vapour phase gave a slight yellow colouration of the agar but again no growth occurred. This indicates that the IpbACB enzymes of $\mathrm{BD} 2$ are able to oxidize biphenyl but that further degradation of the oxidized products of biphenyl does not take place. Analysis of deduced amino acid sequence data and alignments of the IPB 2,3-dioxygenase subunits with the corresponding subunits of BphA1A2A3A4 from Rhodococcus sp. RHA1 (Masai et al., 1995), TodC1C2BA from $P$. putida F1 (Zylstra \& Gibson, 1989), BedC1C2BA from $P$. putida ML2 (Tan et al., 1993) and BphA1A2A3A4 from $P$. pseudoalcaligenes KF707 (Taira et al., 1992) revealed three conserved regions in the reductase ${ }_{\mathrm{IPB}}$ component (IpbA4) likely to bind FAD and $\mathrm{NAD}^{+}$: two of the conserved regions were located at the $\mathrm{N}$-terminus and the middle region of the reductase component IpbA4, respectively, and are centred around a $\beta \alpha \beta$-fold (Mason \& Cammack, 1992). A third conserved sequence forming a $\beta$-sheet was found at the $\mathrm{C}$-terminus of IpbA4 and supposed to bind the O-3 group of the ribityl chain of the flavin moiety of FAD (amino acids 265-275) (Wierenga et al., 1986; Eggink et al., 1990). Conserved sequences with two cysteines and two histidines as putative $[2 \mathrm{Fe}-2 \mathrm{~S}]$ Riesketype cluster ligands were identified in the ferredoxin IpbA3 as well as in the $\alpha$-subunit of the terminal dioxygenase IpbA1 (amino acids 43-65 and 98-121, respectively).

A comparison of the organization of the ipb genes and the corresponding genes of analogous degradative pathways showing the highest homologies is presented in Fig. 3. The operon structure of the biphenyl degradative pathway in R. globerulus P6 (Asturias et al., 1994, 1995) and the toluene degradative pathway in P. putida F1 (Zylstra \& Gibson, 1989) is consistent with the metabolic order of

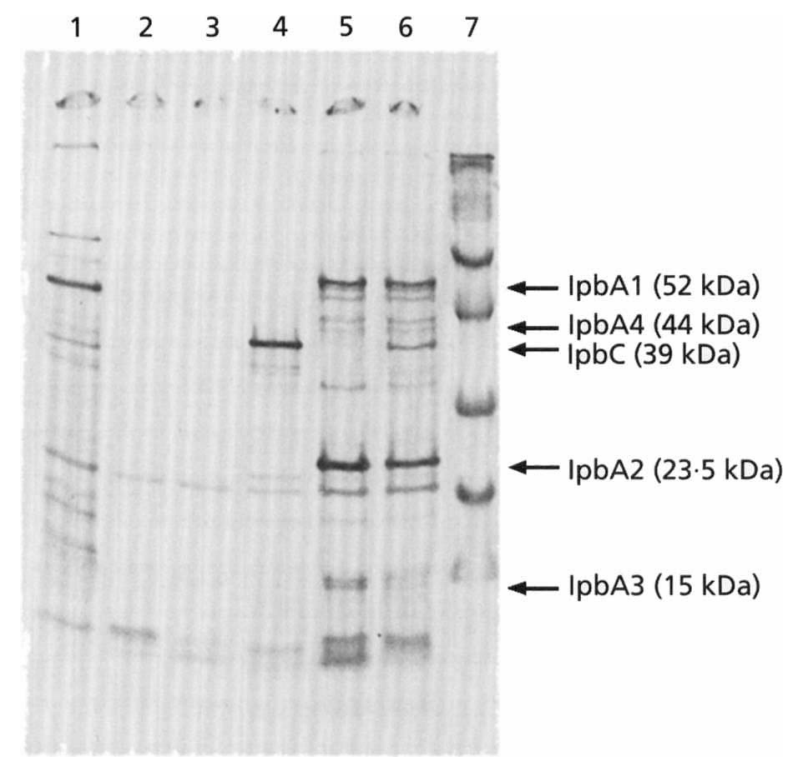

Fig. 4. In vitro expression of ipbAC gene products. Polypeptides were synthesized and labelled with L- $\left[{ }^{35} S\right]$ methionine by an $E$. coli S30 extract system (Promega), separated by SDS-PAGE and detected on an autoradiogram. Lanes: 1, pBestLuc as a positive control $(60.7 \mathrm{kDa}) ; 2$, no DNA template added; 3, pKK223-3 as a negative control; 4, pKKM2 (39 kDa); 5, pKKID5 (52, 44, 23.5 and $15 \mathrm{kDa}) ; 6$, pMK34 $(52,44,39,23.5$ and $15 \mathrm{kDa}) ; 7$, molecular mass markers $(66.0,46.0,30.0,21.5$ and $14.3 \mathrm{kDa})$.

the gene products. In contrast to this, the IPB 2,3dioxygenase genes ( $i p b A 1 A 2 A 3 A 4)$ are followed by a noncoding region of about $300 \mathrm{bp}$ and the gene encoding the meta-cleavage 3-IPC 2,3-dioxygenase (IpbC), which precedes the dihydrodiol dehydrogenase gene $i p b B$. This gene order is only consistent with the $b p h$ genes of the biphenyl degradative pathway in Rhodococcus sp. RHA1 (Masai et al., 1995). Therefore, interestingly, the order of the genes for the meta-cleaving dioxygenase and the dihydrodiol dehydrogenase in $\mathrm{BD} 2$ is reversed with regard to their metabolic order.

\section{Identification of $i p b A$ and $i p b C$ gene products}

The gene products of $i p b A C$ were identified by an in vitro transcription/translation assay using derivatives of the expression vector pKK223-3 as DNA templates. The derivative pKKID5 carries the $4.9 \mathrm{~kb}$ EcoRI fragment of pMKD107 containing the IPB 2,3-dioxygenase genes (ipbA1A2A3A4), whereas pKKM2 contains the $2.5 \mathrm{~kb}$ PstI-HindIII fragment of pMKD107 encoding ipbC (Table 1). The results of SDS-PAGE analysis are shown in Fig. 4. The molecular masses of the expressed polypeptides are consistent with the theoretical values based on the deduced amino acid sequences as described in Table 3. Comparison of lanes 4 (pKKM2) and 5 (pKKID5) with lane 6, which represents transcription/ translation analysis with the plasmid pMK34 carrying $i p b A B C$ under the control of the lactose operon promoter $(\mathrm{Plac})$, shows that expression of $i p b A$ and $i p b C$ under the 
Table 3. ipbA1A2A3A4C gene products from $R$. erythropolis BD2 and their molecular masses

\begin{tabular}{|c|c|c|c|c|}
\hline Gene & $\begin{array}{c}\text { Region of } \\
\text { nucleotide } \\
\text { sequence }\end{array}$ & Protein & $\begin{array}{c}\text { Estimated } \\
\text { molecular } \\
\text { mass } \\
(\mathrm{kDa})\end{array}$ & $\begin{array}{c}\text { Determined } \\
\text { molecular } \\
\text { mass } \\
(\mathrm{kDa})\end{array}$ \\
\hline$i p b A 1$ & $855-2234$ & $\begin{array}{l}\text { Terminal dioxygenase } \\
\text { (iron-sulfur protein), } \\
\text { large subunit }\end{array}$ & $50 \cdot 6$ & $52 \cdot 0$ \\
\hline$i p b A 2$ & $2319-2879$ & $\begin{array}{l}\text { Terminal dioxygenase } \\
\text { (iron-sulfur protein), } \\
\text { small subunit }\end{array}$ & $20 \cdot 6$ & $23 \cdot 5$ \\
\hline$i p b A 3$ & $2891-3211$ & Ferredoxin $_{\mathrm{IPB}}$ & $11 \cdot 8$ & $15 \cdot 0$ \\
\hline$i p b A 4$ & $3211-4446$ & Ferredoxin $_{\text {IPB }}$ reductase & $45 \cdot 3$ & $44 \cdot 0$ \\
\hline$i p b C$ & $4774-5724$ & 3-IPC 2,3-dioxygenase & $34 \cdot 9$ & $39 \cdot 0$ \\
\hline
\end{tabular}

control of the hybrid promoter of the lactose and the tryptophan operon $(\mathrm{P} t a c)$ is much more efficient than from Plac. Some slight bands, undetectable in the negative control lanes 2 and 3 , probably represent truncated polypeptides resulting from internal translational starts. The ferredoxin containing only two methionines, including the one at the start, and the ferredoxin reductase nearly escaped detection.

\section{IPB and 3-IPC 2,3-dioxygenase activities in E. coli carrying a recombinant plasmid}

The $2.6 \mathrm{~kb}$ Not $\mathrm{I}-E c o \mathrm{RV}$ fragment of pMKD107 carrying the 3-IPC 2,3-dioxygenase gene of strain BD2 was cloned in pBluescript II KS and pBluescript II SK, respectively. The resulting plasmids, designated pMK2 and pMK4 (Fig. 1), were transformed into E. coli XL1-Blue. After induction with IPTG and spraying with 3-IPC, E. coli XL1-Blue colonies carrying the recombinant plasmid pMK4 showed meta-cleavage activity while those harbouring pMK2 did not, suggesting that the 3-IPC 2,3dioxygenase was expressed under control of Plac. These recombinant cells exhibited a specific 3-IPC 2,3-dioxygenase activity of $25 \mathrm{nmol} \mathrm{min} \mathrm{mg}^{-1}$. Similar expression levels were obtained with E. coli JM109 carrying the recombinant plasmid pMK34 (encoding ipb $A B C$ ). No further increase of the specific 3-IPC 2,3-dioxygenase activity was found in the presence of the wild-type inducer substrate IPB. Insertion of the $2.6 \mathrm{~kb}$ PstIHindIII fragment carrying the $i p b C$ gene into the expression vector pKK223-3 strongly improved the expression, as indicated by the oxygen-uptake rates of E. coli XL1-Blue cells carrying the recombinant plasmid pKKM2 (Table 4).

The recombinant plasmid pMK34, which carried the $4 \cdot 2 \mathrm{~kb} \mathrm{Bg} / \mathrm{II}-E c o \mathrm{RI}$ fragment of pMKD107 containing the IPB 2,3-dioxygenase genes plus the $2.0 \mathrm{~kb} E c o \mathrm{RI}$ fragment of pMKD119 encoding the 3-IPC 2,3-dioxygenase (Fig. 1 ), was transferred into E. coli XL1-Blue. During growth on LB medium, the $E$. coli XL1-Blue recombinant colonies carrying pMK34 exhibited the blue colouration characteristic of indigo production while those harbouring pMK4 carrying the 3-IPC 2,3-dioxygenase gene did not. Previous publications have shown that several bacteria able to oxidize aromatic hydrocarbons to cisdihydrodiols also catalyse the oxidation of indole to give indigo (Ensley et al., 1983; Clarke \& Laverack, 1984). This indole oxidation was found to be brought about by the dioxygenases mediating the initial activation of the aromatic nucleus. In accordance with this, we recently published data on the IPB-induced indigo formation from indole by R. erytbropolis BD2 (Dabrock et al., 1994). The indigo production by recombinant $E$. coli strains carrying IPB 2,3-dioxygenase genes from strain BD2 was found to be independent of induction with IPTG or IPB. Unfortunately, the rates of the IPB 2,3-dioxygenase were too low to be detected by the polarographic method in the E. coli background.

\section{Inhibitor studies}

Because of the low IPB 2,3-dioxygenase activities in $E$. coli recombinant strains carrying the cloned IPB 2,3dioxygenase, an IPB-2,3-dioxygenase-catalysed TCE degradation could not be demonstrated. To identify the TCE-oxidizing enzyme of the IPB degradative pathway in R. erytbropolis $\mathrm{BD} 2$, the TCE oxidation by IPB-induced $\mathrm{BD} 2$ wild-type cells was determined in the presence of 3chlorocatechol, a competitive inhibitor of meta ringfission dioxygenases (Bartels et al., 1984). After addition of $0.66 \mu \mathrm{mol} 3$-chlorocatechol ( $\mathrm{mg}$ protein) ${ }^{-1}$, the 3-IPC2,3-dioxygenase-catalysed meta ring-fission of 3-IPC was completely inhibited, while $30-60 \%$ of the IPB 2,3dioxygenase activity was still detected in fully induced wild-type cells. Examination of the TCE oxidation activity in the presence of 3-chlorocatechol revealed that cells completely inhibited in meta ring-fission activity still exhibited a TCE oxidation rate of $1.1 \mathrm{nmol} \mathrm{min} \mathrm{m}^{-1}$ (mg protein $)^{-1}$, representing $70 \%$ of the maximum TCE oxidation rates $\left[1.6 \mathrm{nmol} \mathrm{min}{ }^{-1}(\mathrm{mg} \text { protein })^{-1}\right]$ in cells of 
Table 4. Specific activities and substrate specificities of the 3-IPC 2,3-dioxygenase in E. coli

The 3-IPC 2,3-dioxygenase activity [ $\mathrm{nmol} \mathrm{min}^{-1}(\mathrm{mg} \text { protein })^{-1}$ ] was determined polarographically. The strains were induced with IPTG as described in Methods.

\begin{tabular}{|lccc|}
\hline Substrate & E. coli strain & Plasmid & $\begin{array}{c}\text { Dioxygenase } \\
\text { activity }\end{array}$ \\
\hline 3-IPC & XL1-Blue & pMK4 & 25 \\
& XL1-Blue & pMK2 & 0 \\
& JM109 & pMK34 & 22 \\
Catechol & XL1-Blue & pKKM2 & 246 \\
3-Methylcatechol & XL1-Blue & pKKM2 & 118 \\
& XL1-Blue & pKKM2 & 284 \\
\hline
\end{tabular}

strain $\mathrm{BD} 2$ fully induced by IPB. This result, in accordance with the correlation of the linear-plasmidencoded IPB 2,3-dioxygenase and TCE oxidation activity (Dabrock et al., 1994), strongly suggests that the IPBinduced TCE degradation in strain $\mathrm{BD} 2$ is catalysed by the IPB 2,3-dioxygenase of $\mathrm{R}$. erythropolis BD2.

\section{DISCUSSION}

We cloned and sequenced a $5.7 \mathrm{~kb}$ fragment from the linear plasmid of $\mathrm{R}$. erytbropolis BD2 encoding dioxygenases involved in IPB degradation. Sequence analysis of $i p b C$ revealed characteristics of genes encoding extradiol dioxygenases; the strongest homologies were found to functionally equivalent enzymes of biphenyl degradation in Rbodococcus species (Asturias et al., 1994, 1995; Masai et al., 1995) and toluene degradation in P. putida F1 (Zylstra \& Gibson, 1989). The following lines of evidence led to the conclusion that the four ORFs designated ipb A1A2A3A4 encode the components of a multicomponent IPB 2,3-dioxygenase: (i) significant homologies of the products of $i p b A 1 A 2 A 3 A 4$ with functionally related aromatic dioxygenases; (ii) characteristic unidirectional tandem organization of ipb $A 1 A 2 A 3 A 4$ analogous to biphenyl and toluene multicomponent aromatic dioxygenases; (iii) consistent organization of ipb $A 1 A 2 A 3 A 4 C B$ and the equivalent $b p b$ genes in Rhodococcus sp. RHA1; (iv) production of indigo from indole by $E$. coli recombinant strains carrying ipb $A 1 A 2 A 3 A 4 C$; (v) sizes of the ipbA1A2A3A4 and $i p b C$ gene products, which were consistent with analogous dioxygenase proteins. The most significant degrees of homology were found between the $i p b A$ genes in $R$. erytbropolis BD2 and the analogous $b p h$ genes from Rhodococcus sp. RHA1 (Masai et al., 1995) and R. globerulus P6 (Asturias $e t$ al., 1995). These results suggest that the $i p b$ and $b p b$ genes are derived from the same ancestral origin. Interestingly, no predominance of the Rhodococcus-typical GAA codon over GAG for Glu was found. This was also reported for the $b p h$ genes in R. globerulus P6. Based on the high-level sequence identity between equivalent $i p b A$ genes from R. erytbropolis $\mathrm{BD} 2$ and the tod, $t c b$, bed and $b p b$ dioxygenase genes from Pseudomonas strains and the nontypical codon usage, a common non-Rhodococcus phylogenetic origin of these ring-activating dioxygenases in Pseudomonas and Rhodococcus is indicated.

The $6.4 \mathrm{~kb} \mathrm{BclI}$ DNA fragment carrying the ipb genes in the Rhodococcus $-E$. coli shuttle vector $\mathrm{pDA} 71$, which only contained the $\lambda$-promoter of the EcoRI gene, did not express either IPB 2,3-dioxygenase or 3-IPC 2,3-dioxygenase activities in E. coli when grown in the presence of the inducer substrate IPB. This suggests that the natural promoter is not present or not active or that a positive regulator of the $i p b$ genes is missing on the cloned DNA fragment. Since $0.85 \mathrm{~kb}$ of $5^{\prime}$-DNA localized upstream of ipb $A 1$ did not match with the consensus sequences for $E$. coli promoters, we favour the explanation that a Rhodococcus promoter is present but not active in E. coli. Evidence supporting this hypothesis is that 3-IPC 2,3dioxygenase activity was detected in $R$. erytbropolis SQ1(pMKD107) carrying the cloned ipb genes inserted in the shuttle vector $\mathrm{pDA} 71$. Independent of the presence of IPB, SQ1 recombinant strains carrying the 3-IPC 2,3dioxygenase gene only revealed approximately $10 \%$ of the maximal 3-IPC 2,3-dioxygenase activity detected in fully induced BD2 cells. An incomplete promoter site or a missing regulator gene may account for this low basic level of 3-IPC 2,3-dioxygenase activity and the undetectable, low or missing IPB 2,3-dioxygenase activity in SQ1. Another explanation for the low level of 3-IPC 2,3dioxygenase could be a transcription of the ip $b$ genes from multiple promoters; a promoter site induced by IPB might be located far upstream of the ipb $A 1$ start codon and therefore might be missing on the cloned fragment. A transcription from multiple promoters has already been demonstrated for the analogous biphenyl dioxygenase in $P$. putida LB400, where a biphenyl-induced promoter was identified approximately $1.0 \mathrm{~kb}$ upstream of the $i p b A$ start codon and two additional promoter sites were mapped very close to the $i p b A$ start codon (Erickson \& Mondello, 1992). The tight clustering and the head-to-tail organization of the ipb genes in $\mathrm{BD} 2$ suggests that $i p b A 1 A 2 A 3 A 4$ and $i p b C$ are cotranscribed. However, no IPB 2,3-dioxygenase activity was detected in SQ1 cells expressing low 3-IPC 2,3-dioxygenase activity. This might be due to lower specific activities of the IPB dioxygenase as compared to 3-IPC 2,3-dioxygenase activities. This hypothesis is supported by the result that fully induced wild-type cells reveal lower specific activities of the IPB 2,3-dioxygenase $\left(145 \mathrm{nmol} \mathrm{min}{ }^{-1} \mathrm{mg}^{-1}\right)$ than of

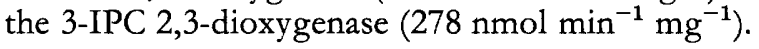

After subcloning of $i p b A 1 A 2 A 3 A 4$ and $i p b C$ genes in different vectors downstream of Plac or Ptac and transfer into $E$. coli cells, polarographic measurements revealed high 3-IPC 2,3-dioxygenase activities in these recombinant E. coli strains, whereas IPB dioxygenase activities were only detectable by the IPB-2,3-dioxygenase-mediated oxidation of indole to indigo. As the indole oxidation is known to be more sensitive than polarographic methods (Jenkins \& Dalton, 1985) and very specific for aromatic dioxygenases (Ensley et al., 1983; Clarke \& Laverack, 1984), we conclude that $i p b A 1 A 2 A 3 A 4$ gene products 
are only poorly active in E. coli. Since the IpbA1, IpbA2, IpbA3 and IpbA4 proteins were expressed in vitro, we suggest that post-translational modifications influencing the binding of $\mathrm{NAD}(\mathrm{P}) \mathrm{H}$ and flavin to the apoenzyme or affecting the coordination of Rieske type iron-sulfur clusters might be responsible for the very low IPB 2,3dioxygenase activities. A modified assembly of the IPB 2,3-dioxygenase components in $E$. coli could change domain packing, which is important for the orientation of the prosthetic groups of multicomponent enzymes, as has been shown for the phthalate dioxygenase reductase in Burkbolderia (Pseudomonas) cepacia (Correll et al., 1992). A change in the assembly could also affect the orientation of the components of the IPB dioxygenase. This might inhibit the rapid distribution of electrons (Correll et al., 1992). As edge-to-edge distances and electronic coupling between donor and receptor components are crucial parameters determining the rates of biological electron transfer reactions (Correll et al., 1985), a change in subunit interaction could drastically reduce the IPB 2,3-dioxygenase activity. The rather short putative Shine-Dalgarno sequence found upstream of $i p b A 4$ as well as the strong stem-loop structure of approximately 60 bonds per stem which has been mapped upstream of the ipbA4 start codon could account for the poor expression of $i p b A 4$ during in vitro expression.

Analysis of the deduced protein sequence of the product of ipb $A 4$ (reductase IPB $_{\text {) }}$ revealed two conserved regions with a consensus sequence of Xaa-Gly-Xaa $-\mathrm{Xly}_{2}-\mathrm{Xaa}_{3}-$ $\mathrm{Ala}$ (or a homologous amino acid)- $\mathrm{Xaa}_{6}$-Gly (where Xaa is any amino acid) predicted to bind $\mathrm{NAD}^{+}$and $\mathrm{FAD}^{+}$ and a third conserved region located at the $\mathrm{C}$-terminus, consisting of a Thr-Xaa ${ }_{6}$-Ala-Xaa-Gly-Asp consensus sequence predicted to bind FAD (Wierenga et al., 1986; Eggink et al., 1990). The consensus sequence $\mathrm{CXHX}_{16-}$ ${ }_{17} \mathrm{CXXH}$ of Rieske iron-sulfur proteins for the binding of a [2Fe-2S] cluster (Rieske et al., 1964) was present in the amino acids of the deduced $i p b A 1$ and $i p b A 3$ products. These observations suggest that the IPB 2,3-dioxygenase in $\mathrm{BD} 2$ consists of three protein components, the terminal oxygenase (protein IpbA1 and A2), the intermediate Rieske iron-sulfur ferredoxin (IpbA3) and an NADH(Rieske iron-sulfur) ferredoxin oxidoreductase (protein IpbA4). Based on these characteristics in the electron transport chain, we conclude that the IPB 2,3-dioxygenase in $R$. erytbropolis $\mathrm{BD} 2$ belongs to the Class IIB ringactivating dioxygenases (Batie et al., 1987).

Very recently, a multicomponent biphenyl dioxygenase (BphA) was reported to be involved in biphenyl degradation by Rhodococcus sp. RHA1 (Masai et al., 1995); it exhibits significant amino acid identity to the products of the ipbA genes of $\mathrm{BD} 2$. As R. erytbropolis $\mathrm{BD} 2 \mathrm{did}$ not grow with biphenyl as sole carbon and energy source but was able to convert biphenyl to the yellow meta-cleavage product, different substrate specificities of the lower IPB and BPH pathway enzymes can be assumed. The genes encoding lower IPB pathway enzymes have not been mapped so far and it is not known whether they are located on the linear transmissible plasmid pBD2 like the IPB and the 3-IPC 2,3-dioxygenase genes.
The IPB-induced TCE degradation and the correlation of the plasmid-encoded IPB degradative pathway with the capability of TCE co-oxidation strongly suggested an IPB pathway dioxygenase being responsible for the oxidation of TCE. As the biochemical and the molecular analysis of the IPB pathway in strain $\mathrm{BD} 2$ revealed two dioxygenases, the ring-activating IPB 2,3-dioxygenase and the metacleavage 3-IPC 2,3-dioxygenase, to be implicated in IPB oxidation, one of these two key dioxygenases was suggested to catalyse TCE co-oxidation. Inhibitor studies, together with the previous results on the IPB-induced TCE degradation (Dabrock et al., 1992), led to the conclusion that the IPB 2,3-dioxygenase catalyses TCE oxidation in BD2. To our knowledge, this interesting enzyme is the first aromatic dioxygenase in a Grampositive bacterium capable of TCE oxidation. Further biochemical studies are underway in our laboratory to shed more light on the structure-function relationship of the linear-plasmid-encoded IPB 2,3-dioxygenase and to elucidate the mechanism of IPB-2,3-dioxygenase-catalysed TCE oxidation.

\section{ACKNOWLEDGEMENTS}

This work was supported by grant no. GO178/24-1 from the Deutsche Forschungsgemeinschaft. M. Keßeler was supported by the Fonds der Chemischen Industrie. We thank V. Mueller for critical reading of the manuscript. We are grateful to Dr B. Dabrock for the kind providing of unpublished data on inhibitor studies.

\section{REFERENCES}

Anderson, M. L. M. \& Young, B. D. (1985). Quantitative filter hybridization. In Nucleic Acid Hybridization, pp. 73-110. Edited by B. D. Hames \& S. J. Higgins. Oxford: IRL Press.

Arciero, D., Vannelli, T., Logan, M. \& Hooper, A. B. (1989). Degradation of trichloroethylene by the ammonia-oxidizing bacterium Nitrosomonas europaea. Biochem Biopbys Res Commun 159, 640-643.

Asturias, J. A., Eltis, L. D., Prucha, M. \& Timmis, K. N. (1994). Analysis of the three 2,3-dihydroxybiphenyl 1,2-dioxygenases found in Rbodococcus globerulus P6. J Biol Cbem 269, 7807-7815.

Asturias, J. A., Diaz, E. \& Timmis, K. N. (1995). Evolutionary relationship of the biphenyl dioxygenase of the gram-positive bacterium $R$ bodococcus globerulus $\mathrm{P} 6$ to multicomponent dioxygenases of gram-negative bacteria. Gene 156, 11-18.

Bachmann, B. J. (1987). Linkage map of Escherichia coli $\mathrm{K}-12$, edition 7. In Eschericbia coli and Salmonella typhimurium: Cellular and Molecular Biology, vol. 2, pp. 807-876. Edited by F. C. Neidhardt, J. L. Ingraham, K. Brooks Low, B. Magasanik, M. Schaechter \& H. E. Umbarger. Washington, DC: American Society for Microbiology.

Bartels, I., Knackmuss, H.-J. \& Reineke, W. (1984). Suicide inactivation of catechol 2,3-dioxygenase from Pseudomonas putida mt-2 by 3-halocatechols. Appl Environ Microbiol 47, 500-505.

Batie, C. J., LaHaie, E. \& Ballou, D. P. (1987). Purification and characterization of phthalate oxygenase and phthalate oxygenase reductase from Pseudomonas cepacia. J Biol Chem 262, 1510-1518. 
Bullock, W. O., Fernandez, J. M. \& Short, J. M. (1987). XL1-blue: a high efficiency plasmid transforming $\operatorname{rec} A$ Escherichia coli strain with beta-galactosidase selection. BioTechniques 5, 376-378.

Clarke, P. H. \& Laverack, P. D. (1984). Growth characteristics of Pseudomonas strains carrying catabolic plasmids and their cured derivatives. FEMS Microbiol Lett 24, 109-112.

Correll, C. C., Batie, C. J., Ballou, D. P. \& Ludwig, M. L. (1985). Crystallographic characterization of phthalate oxygenase reductase, an iron-sulphur flavoprotein from Pseudomonas cepacia. J Biol Chem 260, 14633-14635.

Correll, C. C., Batie, C. J., Ballou, D. P. \& Ludwig, M. L. (1992). Phthalate dioxygenase reductase: a modular structure for electron transfer from pyridine nucleotides to [2Fe-2S]. Science 258, 1604 1610.

Dabbs, E. R., Gowan, B. \& Andersen, S. J. (1990). Nocardioform arsenic resistance plasmids and construction of $R$ bodococcus cloning vectors. Plasmid 23, 242-247.

Dabrock, B., Riedel, J., Bertram, J. \& Gottschalk, G. (1992). Isopropylbenzene (cumene) - a new substrate for the isolation of trichloroethene-degrading bacteria. Arch Microbiol 158, 9-13.

Dabrock, J., Keßeler, M., Averhoff, B. \& Gottschalk, G. (1994). Identification and characterization of a transmissible linear plasmid from Rhodococcus erytbropolis $\mathrm{BD} 2$ specifying for isopropylbenzene and trichloroethene (TCE) catabolism. Appl Environ Microbiol 60, 853-860.

Eggink, G., Engel, H., Vriend, G., Terpstra, P. \& Witholt, B. (1990). Rubredoxin reductase of Pseudomonas oleovorans. Structural relationship to other flavoprotein oxidoreductases based on one NAD and two FAD fingerprints. $J$ Mol Biol 212, 135-142.

Ensley, B. D. (1991). Biochemical diversity of trichloroethylene metabolism. Annu Rev Microbiol 45, 283-299.

Ensley, B. D., Ratzkin, B. J., Osslund, T. D., Simon, M. J., Wackett, L. P. \& Gibson, D. T. (1983). Expression of naphthalene oxidation genes in Escberichia coli results in the biosynthesis of indigo. Science 222, 167-169.

Erickson, B. D. \& Mondello, F. J. (1992). Nucleotide sequencing and transcriptional mapping of the genes encoding biphenyl dioxygenase, a multicomponent polychlorinated-biphenyl-degrading enzyme in Pseudomonas strain LB400. J Bacteriol 174, 2903-2912.

Evers, J., Freier-Schröder, D. \& Knackmuss, H.-J. (1990). Selection of trichloroethene (TCE) degrading bacteria that resist inactivation by TCE. Arch Microbiol 154, 410-413.

Folsom, B. R., Chapman, P. J. \& Pritchard, P. H. (1990). Phenol and trichloroethylene degradation by Pseudomonas cepacia G4: kinetics and interactions between substrates. Appl Environ Microbiol 56, 1279-1285.

Furukawa, K. \& Miyazaki, T. (1986). Cloning of a gene cluster encoding biphenyl and chlorobiphenyl degradation in Pseudomonas pseudoalcaligenes. J Bacteriol 166, 392-398.

Jenkins, O. R. \& Dalton, H. (1985). The use of indole as a spectrophotometric assay substrate for toluene dioxygenase. FEMS Microbiol Lett 30, 227-231.

Masai, E., Yamada, A., Healy, J. M., Hatta, T., Kimbara, K., Fukuda, M. \& Yano, K. (1995). Characterization of biphenyl catabolic genes of gram-positive polychlorinated biphenyl degrader Rhodococcus sp. strain RHA1. Appl Environ Microbiol 61, 2079-2085.

Mason, J. R. \& Cammack, R. (1992). The electron-transport proteins of hydroxylating bacterial dioxygenases. Annu Rev Microbiol 46, 277-305.

Miller, J. H. (1972). Experiments in Molecular Genetics. Cold Spring Harbor, NY: Cold Spring Harbor Laboratory.
Miller, R. E. \& Guengerich, F.P. (1983). Metabolism of trichloroethylene in isolated hepatocytes, microsomes, and reconstituted enzyme systems containing cytochrome P-450. Cancer Res 43, 1145-1152.

Nelson, M. J. K., Montgomery, S. O. \& Pritchard, P. H. (1986). Aerobic metabolism of trichloroethylene by a bacterial isolate. Appl Environ Microbiol 52, 383-384.

Nelson, M. J. K., Montgomery, S. O. \& Pritchard, P. H. (1988). Trichloroethylene metabolism by microorganisms that degrade aromatic compounds. Appl Environ Microbiol 54, 604-606.

Oldenhuis, R., Vink, R. L. J. M., Janssen, D. \& Witholt, B. (1989). Degradation of chlorinated aliphatic hydrocarbons by Metbylosinus trichosporium OB3b expressing soluble methane monooxygenase. Appl Environ Microbiol 55, 2819-2826.

Quan, S. \& Dabbs, E. R. (1993). Nocardioform arsenic resistance plasmid characterization and improved $R$ bodococcus cloning vectors. Plasmid 29, 74-79.

Rieske, J. S., MacLennan, D. H. \& Coleman, R. (1964). Isolation and properties of an iron-protein from the (reduced coenzyme Q)cytochrome c reductase complex of the respiratory chain. Biochem Biophys Res Commun 15, 338-344.

Sambrook, J., Fritsch, E. F. \& Maniatis, T. (1989). Molecular Cloning: a Laboratory Manual, 2nd edn. Cold Spring Harbor, NY: Cold Spring Harbor Laboratory.

Sanger, F., Nicklen, S. \& Coulson, A. R. (1977). DNA sequencing with chain-terminating inhibitors. Proc Natl Acad Sci USA 74, 5463-5467.

Schägger, H. \& von Jagow, G. (1987). Tricine-sodium dodecyl sulfate-polyacrylamide gel electrophoresis for the separation of proteins in the range from 1 to $100 \mathrm{kDa}$. Anal Biochem 166, 368-379.

Schmidt, K., Liaanen-Jensen, S. \& Schlegel, H. G. (1963). Die Carotinoide der Tbiorbodaceae. Arch Microbiol 46, 117-126.

Taira, K., Hirose, J., Hayashida, S. \& Furukawa, K. (1992). Analysis of $b p b$ operon from the polychlorinated biphenyl-degrading strain of Pseudomonas pseudoalcaligenes KF707. J Biol Chem 267, 4844-4853.

Tan, H.-M., Tang, H.-Y., Joannou, C. L., Abdel-Wahab, N. H. \& Mason, J. R. (1993). The Pseudomonas putida ML2 plasmid-encoded genes for benzene dioxygenase are unusual in codon usage and low in G + C content. Gene 130, 33-39.

Van der Meer, J. R., van Neerven, A. R., de Vries, E. J., De Vos, W. M. \& Zehnder, A.J. (1991). Cloning and characterization of plasmid-encoded genes for the degradation of 1,2-dichloro-, 1,4dichloro-, and 1,2,4-trichlorobenzene of $P_{\text {seudomonas sp. strain P51. }}$ J Bacteriol 173, 6-15.

Vieira, J. \& Messing, J. (1987). Production of single-stranded plasmid DNA. Methods Enzymol 153, 3-11.

Wackett, L. P. \& Householder, S. R. (1989). Toxicity of trichloroethylene to Pseudomonas putida $\mathrm{F} 1$ is mediated by toluene dioxygenase. Appl Environ Microbiol 55, 2723-2725.

Wackett, L. P., Brusseau, G. A., Householder, S. R. \& Hanson, R. S. (1989). Survey of microbial oxygenases: trichloroethylene degradation by propane-oxidizing bacteria. Appl Environ Microbiol 55, 2960-2964.

Whited, G. M. \& Gibson, D. T. (1991). Toluene-4-monooxygenase, a three-component enzyme system that catalyzes the oxidation of toluene to $p$-cresol in Pseudomonas mendocina KR1.J Bacteriol 173, 3010-3016.

Wierenga, R. K., Terpstra, P. \& Hol, W. G. J. (1986). Prediction of the occurrence of the ADP-binding $\beta \alpha \beta$-fold in proteins, using an amino acid sequence fingerprint. $J$ Mol Biol 187, 101-107. 
Yanisch-Perron, C., Vieira, J. \& Messing, J. (1985). Improved M13 phage cloning vectors and host strains: nucleotide sequences of the M13mp18 and pUC19 vectors. Gene 33, 103-119.

Zylstra, G. J. \& Gibson, D. T. (1989). Toluene degradation by Pseudomonas putida F1. Nucleotide sequence of the todC1C2B ADE genes and their expression in Escherichia coli. J Biol Chem 264, 14940-14946.

Received 15 April 1996; revised 23 June 1996; accepted 12 July 1996. 